\title{
THE INVESTIGATIONS OF A PECULIARITIES OF PYROCARBON GAS PHASE DENSIFICATION OF POWDERS OF THE CATALYTIC CARBON FORMATIONS (CCFS), OBTAINED ON NICKEL
}

\author{
S.G. Fursov, V.V. Guida, S.A. Lyashenko, M.V. Meltyukhov, O.S. Aulova \\ National Science Center "Kharkov Institute of Physics and Technology", \\ Kharkiv, Ukraine \\ E-mail: igor@kipt.kharkov.ua; tel./fax +38(057)335-39-83
}

Investigations on gas-phase densification of the catalytic carbon formations (CCFs), obtained on nickel, using the method of radially driven pyrolysis zone were carried out. Straight dependence of the brittle strength of the CCFs, bonded with pyrocarbon (CCFBPyC), from the CCFs morphology, was shown. It was determined, that the result of decreasing of an amount of fibrous, fine-grained CCFs component is the increasing of strength of the pyrocarbon matrix . For the first time, carbon/carbon composite materials (CCCM ) without cracks, which contain refined or not-refined from nickel, carbon nanomaterials (CNM), were obtained.

\section{INTRODUCTION}

Discovering of fullerenes in 1985 [1] and developing the technology of obtaining them in macroscopic amounts had initiated a systematic research of carbon surface structures: fullerens, single-walled (SWNT) and multi-walled (MWNT) carbon nanotubes, carbon nanofibers (CNF) and carbon nanomaterials (CNM), which include these structures, amorphous carbon or graphite. Many methods of producing SWNTs can be combined into 2 groups: sublimation - desublimation of graphite and catalytic pyrolysis of gaseous (the so-called CVD process), liquid and solid hydrocarbons and aqueous solutions [2-4]. In the National Science Center Kharkov Institute of Physics and Technology (NSC KIPT) the first experiments on the synthesis of SWNTs by the CVD method were carried out in 1982-1987 [5], at a gas-phase installation "AGAT-1.6". Later on, the numerous studies of the methods of obtaining, properties and areas of practical application of SWNTs and CNM, based on them, were carried out on the installations AGAT-1.6, AGAT-2.0, AGAT-3.2 [6-9]. Almost all SWNTs described in the literature are covered at both ends by catalyst and CNM particles. Cleaning the tubes from catalysts and impurities and opening their cavity is carried out by various oxidizing methods. CNM, obtained in NSC KIPT by the catalytic pyrolysis of methane or propane-butane on the transition metals-Fe, $\mathrm{Co}, \mathrm{Ni}$, in the temperature range $600 \ldots 800^{\circ} \mathrm{C}$, using CCFs, as a carrier, in most of the cases were not cleaned and were not opened. Therefore, they are conglomerates of entangled MWNTs and 30...40 wt.\% of the soot, with catalyst particles encapsulated in them [10]. In the NSC KIPT, these conglomerates were named catalytic carbon formations - CCFs. When they are ground, a black powder with particles of irregular shape, mainly fibrous and acicular, with a large (up to $40 \mathrm{wt} \%$ ) fraction of less than $50 \mu \mathrm{m}$, is formed. An analogue of this CCFs is the material "Taunit" produced by "NanoTechCenter Ltd", Tambov $[11,12]$. It is a black powder of CNT agglomerates with the dimensions of $40 \ldots 60 \mu \mathrm{m}$, bulk density $0.42 \ldots 0.45 \mathrm{~g} / \mathrm{cm}^{3}$ and pycnometric density $-1.6 \mathrm{~g} / \mathrm{cm}^{3}$. It is obtained by the CVD method, in propane-butane, at $T=650{ }^{\circ} \mathrm{C}$, in a vertical cyclic reactor on a $\mathrm{NiO}-\mathrm{MgO}$ catalyst, with purification in $30 \% \mathrm{HNO}_{3}$ solution and ultra-sonic dispersion in distilled water. The CCFs and "Taunit" microstructures are shown in Fig. 1.

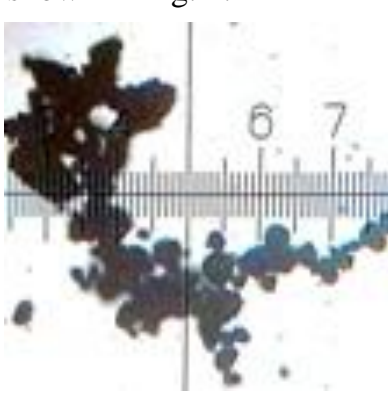

$a$

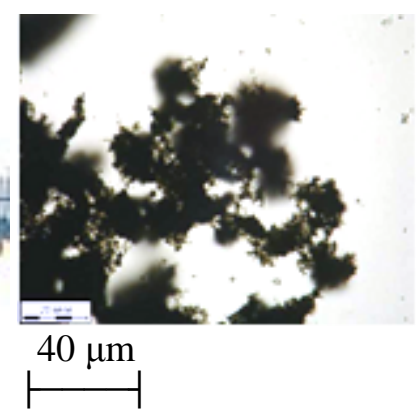

$b$
Fig. 1. Micrographs of materials: $a-C C F s$ NSC KIPT, scale division - $10 \mu \mathrm{m}$; $b$ - "Taunit"

Earlier, including within the framework of STCU projects No 293, 1870, a number of experiments were carried out on the deposition of pyrocarbon (PyC) from methane or propane-butane, both on mixtures of graphite powders with $\mathrm{Ni}, \mathrm{Co}, \mathrm{Fe}$, and on $\mathrm{CCF}$ s containing these metals. When obtaining a carbon-carbon composite material (CCCM), in the form of CCFs bonded with PyC (CCFBPyC), both isothermal and thermogradient densification with pyrocarbon, by the method of radially driven pyrolysis zone, was used.

Heating of the CCFs in the experiments, conducted by this method, was carried out either by the heaters or by the direct passing of an alternate current through the CCFs. In the experiments, various technological methods were used to prevent cracking of the CCFBPC. In the most of the cases, a material without cracks, chips and ruptures was not obtained, due to its brittle fractureFig. 2.

No single mechanism of destruction of the CCFBPC had been identified. It was assumed that the main reason is the swelling of the material, not hardened by $\mathrm{PyC}$, due to the formation of CCFs in it, at temperatures 
above $600{ }^{\circ} \mathrm{C}$. The reasons for the destruction could also be:

- fibrous structure of CCF powders, which promotes their agglomeration (including forming of an anisotropic structures), during blanks moulding;

- the difference of the coefficients of linear thermal expansion (CLTE) of the CCFs, CCFBPyC and materials involved in the process of densification of the CCFs with PyC: graphite, PyC, graphite bonded with pyrocarbon (GBPyC), asbestos cloth, densificated with $\mathrm{PyC}$, Mo or CCCM heater (Fig. 2), etc.;

- decrease of the quantitative yield of $\mathrm{PyC}$ in the pyrolysis zone (up to the formation of the soot) from a mixture of methane and hydrogen, formed during catalysis [13] and, as a consequence, a decrease in the strength of the CCFBPyC;

- adsorption of hydrogen on the catalyst and CCFs [14], with the possible formation of closed gas inclusions, which, as in the case of hydrogen embrittlement of metals, can be detonators of destruction, when internal and external mechanical and thermal stresses appear.

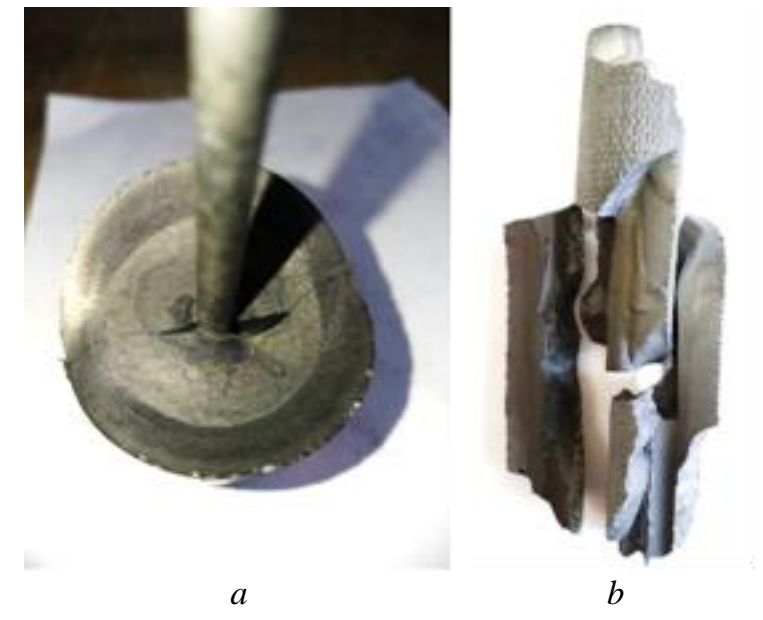

Fig. 2. The nature of cracking in CCFBPyC: $a$-with Mo heater; $b$-with CCCM heater

The aim of this study was to obtain CCCM CCFBPyC without cracks, by direct passage of alternate current through the CCFs, for further research and practical application.

\section{EXPERIMENTAL PROCEDURE}

The CCFs powders were obtained by their production on $\mathrm{Ni}$ powder, with a specific surface of $0.8 \mathrm{~m}^{2} / \mathrm{g}$, at $T=800^{\circ} \mathrm{C}$, in a methane medium. The production of CCFs was carried out in an AGAT-3.2 unit, in a "shaft furnace" ShF [9]. As a catalyst carrier, the CCFs were used themselves. Powders were ground manually to a fraction of less than $315 \mu \mathrm{m}$.

In the experiments were used CCFs powders from the processes ShF-10, ShF-13, ShF-16, with the receipt time: 59, 64 and $61 \mathrm{~h}$, pycnometric density $\rho_{\mathrm{PCN}}$ : 2.14, 2.09, and $2.04 \mathrm{~g} / \mathrm{cm}^{3}$, concentration of $\mathbf{N i}\left(\mathbf{C}_{\mathbf{N i}}\right)-\mathbf{3 . 0 0}$; 2.47; 1.64 wt. $\%$, respectively, and $\mathrm{Ni}$-free powder from the process ShF-16 - ShF-16R, with $\rho_{P C N}=1.97 \mathrm{~g} / \mathrm{cm}^{3}$, $\mathbf{C}_{\mathbf{N i}}=\mathbf{0 . 0 3}$ wt. $\%$ (exp. 3), $\boldsymbol{\rho}_{\mathbf{P C N}}=\mathbf{1 . 9 6} \mathrm{g} / \mathrm{cm}^{3}, \mathbf{C}_{\mathbf{N i}}=$ $\mathbf{0 . 0 1 2 2}$ wt.\%. (exp. 4) - Table 1. Removal of Ni from ShP-16 was carried out by thermal refining in a vacuum of $\mathbf{1 0}^{-\mathbf{3}} \mathrm{atm}$, in CCCM tooling [15], at $T=2650^{\circ} \mathrm{C}$, during the $0.5 \mathrm{~h}$.

$\mathbf{C}_{\mathrm{Ni}}$ in CCFs was determined by its ash content, proceeding from the $\mathbf{N i}$ content in $\mathbf{N i O}=78.58$ wt. $\%$. The ash content was determined after the oxidation of CCFs in air, at $T=900^{\circ} \mathrm{C}$, during the $54 \ldots 56 \mathrm{~h}$.

The main characteristics of "filler - binder" systems are the particle size distribution and their surface area. The size distribution of the CCFs particles was measured by sieve analysis, on a vibrating sieve "029", according to a standard technique. During the analyzes, it was found that the fractions of CCFs less than $200 \mu \mathrm{m}$ are agglomerated. The maximum size at which selfdestruction of the CCFs agglomerates did not occur was $\sim 100 \mu \mathrm{m}$ (see Table 1), which is consistent with the results of [16]. Therefore, to prevent agglomeration, fractions of CCFs less than $200 \mu \mathrm{m}$ were sieved by hand, with loading 10 duralumin nuts M10, into each sieve with CCFs (see index $\mathbf{n}$, Table 1). The size distribution of the agglomerated CCFs, in the powder prepared for densification with PyC, could be determined only by the BET method. Due to the lack of equipment for its production, this characteristic of the powder was not determined. For the same reason and also because of the lack of information about the effect of the specific surface area on the mechanical properties of the CCFBPyC, its measurement was not planned before the experiments. Instead, for a comparative assessment of the CCFs powders, the density of their "free" packing $\boldsymbol{\rho}_{\text {FREE }}$, the density after compaction - $\boldsymbol{\rho}_{\text {COMP }}$ and pycnometric density - $\boldsymbol{\rho}_{\mathbf{P C N}}$ (determined according to the standard method in kerosene) were measured by the well-known standard methods (see Table 1).

To load the powders, containers were made in the form of single-layer shells of AT-3 asbestos cloth (exps. 1-3) and carbon fabric URAL-T-22 (exps. 4-5), impregnated with $50 \%$ water solution of PVA, with a bottom fixed in them. The top of the container was closed with a lid on a loose fit. The bottom and the cover were made of graphite EG-0 (exps. 1-4) and GBPyC-EG-0 (exp. 5), with conical current concentrators in CCFs, $\varnothing 20 \times 10 \mathrm{~mm}$. Current concentrators were used to facilitate the formation of a central electrically conductive cord in the blank, in the initial period of its PyC densification. In the middle of the shell, a paper cup for the TCA quartz cover was fixed (Fig. 3). The blanks were molded by vibration densification of dry CCF powder, got filled into a container without a lid, on an IV-107 vibration stand, during the $5 \mathrm{~min}$, in a place with a maximum vibration amplitude - in exps. 1-3 and strictly in the center - in exps. 4-5. The lid was installed in the container before the end of its compaction on the vibration stand. Densification of CCFs with pyrocarbon was carried out in a gas-phase unit AGAT-1.6, in a methane medium with an overpressure of $300 \mathrm{~mm}$ w.c., by the method of radially driven pyrolysis zone, with direct passage of alternate current through the CCFs and the following parameters: the speed of the pyrolysis zone: $\boldsymbol{v}_{\mathbf{P Z}}=2 \mathrm{~mm} / \mathrm{h}(\exp .1)$ and $0.5 \mathrm{~mm} / \mathrm{h}$ (exps. 2-5), the temperature in the pyrolysis zone: $\boldsymbol{T}_{\mathbf{P Z}}=900{ }^{\circ} \mathrm{C}$. At the beginning, middle and end of the process, the temperature distribution along the container radius was measured, with the calculation of the temperature gradient 
$\Delta \boldsymbol{T}$. In the middle of the process, to increase the densification time and the final density of the CCFBPyC, a thermocouple (TCA) was pushed into the pyrolysis zone with $\boldsymbol{T}_{\mathbf{P Z}}=950{ }^{\circ} \mathrm{C}$ (exps. 3-5).
Cooling of the container in the exps. 1,2 - unregulated, with speeds -7000 and $1020^{\circ} \mathrm{C} / \mathrm{h}$, in exps. 3-5 adjustable, with speed $150{ }^{\circ} \mathrm{C} / \mathrm{h}$. Mechanical processing of the CCFBPyC was carried out on a $1 \mathrm{~K} 62$ lathe.

Table 1

CCFs, CCFBPyC parameters in experiments 1-5

\begin{tabular}{|c|c|c|c|c|c|c|c|c|c|c|c|c|c|}
\hline \multicolumn{14}{|c|}{ Experiment No } \\
\hline & & \multicolumn{2}{|c|}{1} & \multicolumn{2}{|c|}{2} & \multicolumn{2}{|c|}{3} & \multicolumn{2}{|c|}{4} & \multicolumn{4}{|c|}{5} \\
\hline \multicolumn{2}{|r|}{$\begin{array}{l}\text { Brand of } \\
\text { powder }\end{array}$} & \multicolumn{2}{|c|}{ ShP-10 } & \multicolumn{2}{|c|}{ ShP-13 } & \multicolumn{2}{|c|}{ ShP-16R } & \multicolumn{2}{|c|}{ ShP-16R } & \multicolumn{3}{|c|}{ ShP-16 } & $\begin{array}{l}\text { EG-0, } \\
\text { exps. }\end{array}$ \\
\hline \multicolumn{2}{|c|}{ Fraction, $\mu \mathrm{m}$} & \multicolumn{2}{|c|}{$0-315 \mu \mathrm{m}$} & \multicolumn{2}{|c|}{$0-315 \mu \mathrm{m}$} & \multicolumn{2}{|c|}{$0-315 \mu \mathrm{m}$} & $\begin{array}{c}50-315 \\
\mu \mathrm{m}\end{array}$ & $\begin{array}{c}0-315 \\
\mu \mathrm{m}\end{array}$ & $\begin{array}{c}50-315 \\
\mu \mathrm{m}\end{array}$ & $0-3$ & $\mu \mathrm{m}$ & $\begin{array}{c}50-200 \\
\mu \mathrm{m}\end{array}$ \\
\hline \multirow{7}{*}{ 告 } & $>630$ & \multicolumn{2}{|c|}{0.0} & \multicolumn{2}{|c|}{0.0} & \multicolumn{2}{|c|}{0.0} & \multicolumn{2}{|c|}{0.0} & 0.0 & \multicolumn{2}{|c|}{0.0} & 0.0 \\
\hline & $315-400$ & 0.0 & 0.1 & 0.2 & 0.1 & 0.1 & 0.1 & 1.1 & 0.1 & 0.3 & 0.1 & 0.0 & 0.0 \\
\hline & $200-315$ & 21.4 & $\begin{array}{c}21.3 \\
\mathbf{n}\end{array}$ & 21.5 & $\begin{array}{c}22.6 \\
\mathbf{n}\end{array}$ & 21.0 & $\begin{array}{c}20.3 \\
\mathbf{n}\end{array}$ & 29.0 & \multirow{4}{*}{66.4} & 31.0 & 20.5 & $\begin{array}{c}19.9 \\
\mathbf{n}\end{array}$ & 3.8 \\
\hline & $100-200$ & 24.7 & 24.4 & 25.2 & 27.1 & 26.5 & 25.5 & 37.1 & & 36.7 & 27.9 & 27.2 & 45.4 \\
\hline & & & & & & & & & & & & $\mathbf{n}$ & \\
\hline & $50-100$ & 31.6 & $\begin{array}{c}14.0 \\
\mathbf{n}\end{array}$ & 22.1 & $\begin{array}{c}13.3 \\
\mathbf{n}\end{array}$ & 15.3 & $\begin{array}{c}10.9 \\
\mathbf{n}\end{array}$ & 27.0 & & 28.6 & 30.5 & $\begin{array}{c}11.6 \\
n\end{array}$ & 38.3 \\
\hline & $<50$ & 22.3 & 40.2 & 31.0 & 36.9 & 37.1 & 43.2 & 5.8 & 33.5 & 3.4 & 20.9 & 41.3 & 12.5 \\
\hline \multicolumn{2}{|c|}{$\mathrm{C}_{\mathrm{Ni}}$, weigt $\%$} & \multicolumn{2}{|c|}{3.00} & \multicolumn{2}{|c|}{2.47} & \multicolumn{2}{|c|}{0.03} & \multicolumn{2}{|c|}{$\begin{array}{c}0.0122 \\
(0.021<50 \mu \mathrm{m})\end{array}$} & 1.64 & \multicolumn{2}{|c|}{$\begin{array}{c}1.79 \\
(1.9<50 \mu \mathrm{m})\end{array}$} & \\
\hline \multicolumn{2}{|c|}{ receiving $\mathrm{t}, \mathrm{h}$} & \multicolumn{2}{|c|}{59} & & 4 & 61 an & $0.5 \mathrm{~h}$, at & $T=265$ & & & & & \\
\hline & idation $\mathrm{t}, \mathrm{h}$ & & 4 & & 4 & 5 & & 56 & - & 56 & & & - \\
\hline & $\mathrm{PCN}, \mathrm{g} / \mathrm{cm}^{3}$ & & 14 & & 09 & 1.97 & EG-0, & $\begin{array}{r}1 \\
(1.98<\end{array}$ & $\mu \mathrm{m})$ & & $\begin{array}{l}2.04 \\
<50\end{array}$ & & \\
\hline & REE, $\mathrm{g} / \mathrm{cm}^{3}$ & & & & 46 & 0.53 & & 0.55 & & 0.52 & & & \\
\hline & OMP, $\mathrm{g} / \mathrm{cm}^{3}$ & & 47 & & 60 & 0.68 & 0.64 & 0.63 & & 0.59 & & & 0.78 \\
\hline & $\rho_{\mathrm{GBP}, \mathrm{g} / \mathrm{cm}^{3}}$ & & 38 & & 63 & 1.70 & 1.74 & 1.66 & & 1.66 & & & \\
\hline$\vec{n}$ & $\rho_{\mathrm{PCN}}, \mathrm{g} / \mathrm{cm}^{3}$ & & 63 & & 77 & 1.76 & 1.94 & 1.81 & - & 1.82 & & & \\
\hline 崖 & Porosity, \% & & .6 & & 0 & 3.5 & 10.4 & 8.1 & & 8.8 & & & - \\
\hline U & $\delta, \mathrm{PyC}, \mu \mathrm{m}$ & & -1.0 & & -5 & $0.5-1.0$ & - & 7-30 & & 7-30 & & & \\
\hline
\end{tabular}

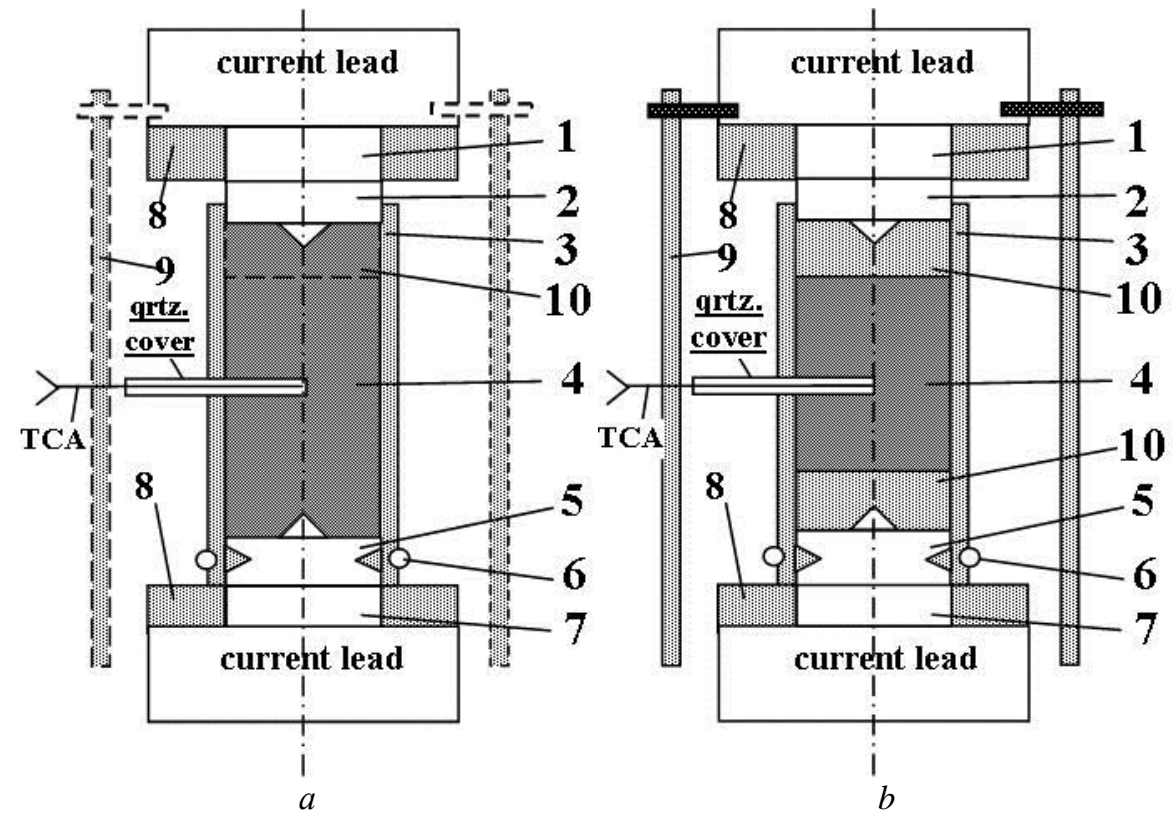

Fig. 3. Shemes of experiments: $a-\mathbf{1}-\mathbf{8}-\exp .1 ; \mathbf{1}-\mathbf{9}-\exp .2 ; \mathbf{1}-\mathbf{1 0}-\exp .3 ; b-\operatorname{exps} .4-5$

Densities ( $\left.\boldsymbol{\rho}_{\mathbf{G B P}}, \boldsymbol{\rho}_{\mathbf{P C N}}\right)$ and open porosity $(\mathbf{P})$ of CCFBPyC was measured by the hydrostatic method, after boiling in water for $4 \mathrm{~h}$ (see Table 1). CCFBPyC polished sections were made on a grinding machine. The
1, 7 - Supports, EG-0;

2, 5 - Current concentrators:

exps. 1-4 - EG-0;

exp. 5 - GBPyc- EG-0;

3 - Shell:

exps. 1-3 - AT-3;

exps. 4-5 - URAL-T-22;

$4-\mathrm{CFs}, \varnothing 70 \mathrm{~mm}$,

exp. 1 - ShP-10;

exp. 2 - ShP-13;

exps. 3, 4-ShP-16R;

exp. 5 - ShP-16;

6 - Shell retainer;

8 - Thermal insulation of the supports, AT-3;

9 - Screen AT-3, 1 layer;

10 - Buffer, Ø 70 mm, EG-0,

exp. $3-0 . .50 \mu \mathrm{m}$;

exps. $4-5-50 \ldots 200 \mu \mathrm{m}$ microstructure of CCF and thin sections of CCFBPyC were analyzed on microscopes MBS-10 and MMR-4. The phase composition of CCF was investigated by 
X-ray structural analysis (diffractometer DRON-1.5, $\mathrm{CuK} \alpha$ radiation, Ni filter) [2].

\section{RESULTS AND DISCUSSION OF EXPERIMENTS}

Due to the limited amount of starting material and the unidentified mechanism of destruction of the CCFBPyC, 5 consecutive experiments were carried out with the analysis of the results and the adjustment of the conditions for their conduct after each experiment.

\section{EXPERIMENT 1}

In experiment 1 (see Fig. 3,a), powder from the ShP-10 process was used. The parameters of the CCFs and CCFBPyC are given in Table 1.

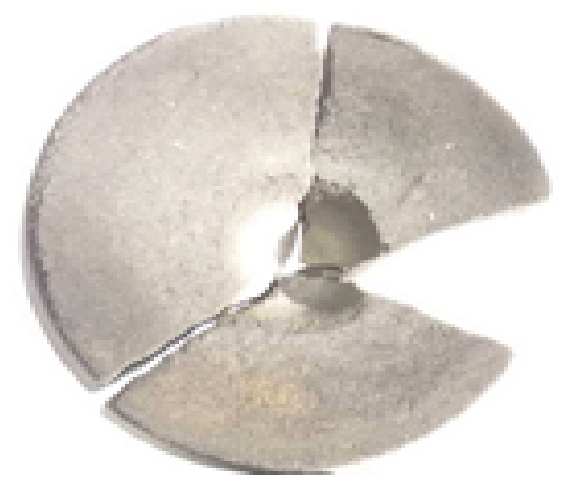

Fig. 4. Cracks at the ends of the container

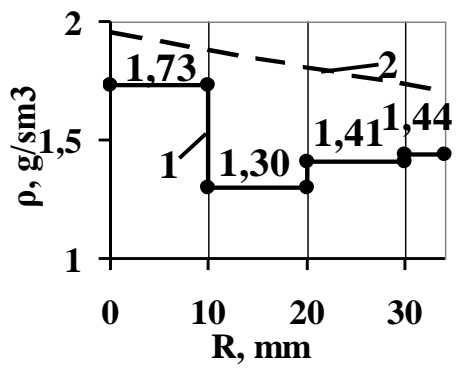

Fig. 5. Density distribution along the container radius: $1-C C F s$ ShP-10, $\boldsymbol{v}_{p z}=2 \mathrm{~mm} / \mathrm{h}$;

$2-E G-0,0 \ldots 200 \mu \mathrm{m}, \boldsymbol{v}_{p z}=0,5 \mathrm{~mm} / \mathrm{h}$

PyC densification was carried out according to the mode: $\boldsymbol{T}_{\mathbf{P Z}}=900{ }^{\circ} \mathrm{C}, \boldsymbol{v}_{\mathbf{P Z}}=2 \mathrm{~mm} / \mathrm{h}$. A high $\boldsymbol{v}_{\mathbf{P Z}}$ was set to prevent the breakage of the blank by the formed CCFs. When measuring the temperature distribution along the radius $(\boldsymbol{R})$ of the container, with the radius of the pyrolysis zone $\left(\boldsymbol{R}_{\mathbf{P Z}}\right)$ equal to $35 \mathrm{~mm}$, the blank, within 10 minutes, underwent a thermal shock: $900 \ldots 700 \ldots 900^{\circ} \mathrm{C}$, in a compressed state, with rates of decrease/growth $T-2400{ }^{\circ} \mathrm{C} / \mathrm{h}$ on the surface and $6000{ }^{\circ} \mathrm{C} / \mathrm{h}-$ in the center. The blank was cooled at a rate of $\sim 7000{ }^{\circ} \mathrm{C} / \mathrm{h}$.

After turning the container, symmetrical cracks were found at its ends adjacent to the current concentrators of the bottom and lid (Fig. 4). The cracks are obviously the result of thermal shock and abrupt cooling of the blank.

The distribution of density along the radius of the CCFBPyC in the section at the middle of the container height is given in Fig. 5. The low density in the range of radii $10 . .20 \mathrm{~mm}$ is due to the premature blocking of the transport porosity of the CCFs both the PyC, at high $\mathbf{v}_{\mathbf{p z}}$ and $T>860^{\circ} \mathrm{C}$ and the CCFs, at $T<860^{\circ} \mathrm{C}$. High temperature gradients $\Delta \boldsymbol{T}$ at the beginning of densification (curve 3, Fig. 6, Table 2) are determined by the presence of up to $40 \mathrm{wt} \%$ of low-heat conductive soot [10] and their low packing density $-0.47 \mathrm{~g} / \mathrm{cm}^{3}$. This density is due to the high content of a finely dispersed fibrous fraction (40 wt. $\%<50 \mu \mathrm{m}$, see Table 1) and anisotropic stacking of CCF agglomerates, when forming the blank on the vibrating stand (exp. 3, Fig. 8,f). Comparison of the temperature distribution in the CCFs and in analogues of its structural components - soot and finely dispersed hammer pyrocarbon, which forms an anisotropic packing during molding (curves 2 and 1, Fig. 6), allows us to consider this assumption quite justified.

\section{EXPERIMENT 2}

High temperature gradients in exp. 1, due to the both high $\boldsymbol{v}_{\mathbf{P Z}}$ and low thermal conductivity of the CCFs, led to an uneven distribution of the density of the CCFBPyC along the radius of the container.

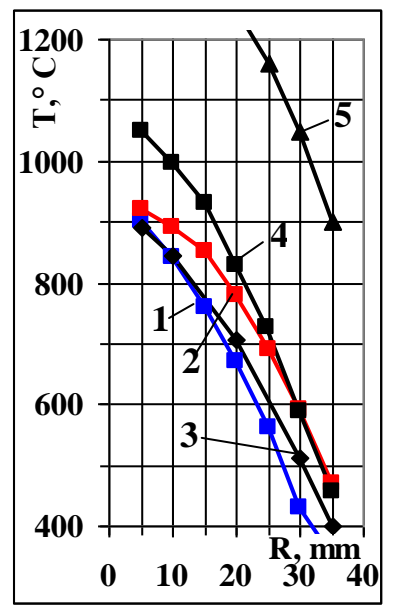

$$
\begin{aligned}
& \underline{\mathrm{T}}_{\mathbf{P Z}}=900^{\circ} \mathrm{C} \\
& \underline{\mathrm{R}_{\mathrm{PZ}}}=5 \mathrm{~mm} \\
& \text { 1-PyC, } \\
& \boldsymbol{\rho}_{\text {СOMP }}=0.73 \mathrm{~g} / \mathrm{cm}^{3} \\
& 2 \text { - Soot, } \\
& \boldsymbol{\rho}_{\text {COMP }}=0.62 \mathrm{~g} / \mathrm{cm}^{3} \\
& 3 \text { - CCFs, } \\
& \boldsymbol{\rho}_{\text {СOMP }}=0.47 \mathrm{~g} / \mathrm{cm}^{3} \\
& \underline{\mathrm{R}}_{\mathbf{P Z}}=17 \mathrm{~mm} \\
& \text { 4-CCFs } \\
& \underline{\mathrm{R}}_{\mathbf{P Z}}=35 \mathrm{~mm} \\
& 5 \text { - CCFs }
\end{aligned}
$$

\begin{tabular}{|c|c|c|c|c|c|c|c|c|}
\hline Curve & $\boldsymbol{R}_{\mathrm{PZ}}$, & \multirow{7}{*}{$\begin{array}{l}\Delta \boldsymbol{T}, \\
{ }^{\mathrm{o}} \mathrm{C} / \\
\mathrm{mm}\end{array}$} & \multicolumn{6}{|c|}{$\boldsymbol{R}, \mathrm{mm}$} \\
\hline No & $\mathrm{mm}$ & & 10 & 15 & 20 & 25 & 30 & 35 \\
\hline 1 & 5 & & 12 & 16 & 18 & 22 & 26 & 16 \\
\hline 2 & 5 & & 6 & 8 & 14 & 18 & 20 & 24 \\
\hline 3 & 5 & & 9 & \multicolumn{2}{|c|}{14} & \multicolumn{2}{|c|}{19.5} & 22 \\
\hline 4 & 17 & & 11 & 13 & 20 & 21 & 27 & 27 \\
\hline 5 & 35 & & \multicolumn{3}{|c|}{-} & 19 & 22 & 30 \\
\hline
\end{tabular}

Fig. 6. Temperature distribution $(\boldsymbol{T})$ along the container radius $(\boldsymbol{R})$ in exp. 1

Table 2

Temperature gradients in experiment 1

Therefore, in exp. 2, in order to prevent premature blocking of the transport porosity, it was decided to reduce the values of technological parameters responsible for the high rate of temperature rise in the zone of carbon formation $-\Delta \boldsymbol{T}$ and $\boldsymbol{v}_{\mathbf{P Z}}$. A decrease in $\Delta \boldsymbol{T}$ expands the zone of carbon deposition, but earlier starts the process of self-deactivation of the catalyst and reduces the yield of CCFs in the volume of the blank. The blocking of transport porosity occurs, therefore, later. This contributes to an increase in the thickness of the PyC layer and an increase in the strength of CCCM. To reduce $\Delta \boldsymbol{T}$, a screen 9 of 1 layer of asbestos cloth AT-3 was in- 
stalled in $25 \ldots 30 \mathrm{~mm}$ from the surface of the container (see Fig. 3,a). $\mathbf{v}_{\mathbf{P Z}}$ was reduced to $0.5 \mathrm{~mm} / \mathrm{h}$, taking into account the uniform distribution of density along the radius of the container, after densification of EG-0 graphite powder, fraction $0 \ldots 200 \mu \mathrm{m}$, at this rate - dashed curve 2, Fig. 5.

CCFs ShP-10 were replaced by CCFs ShP-13, because their mass was enough to carry out at least 2 experiments. The parameters of the CCFs and CCFBPyC are given in Table 1.

The PyC densification was carried out according to the mode: $\boldsymbol{T}_{\mathbf{P Z}}=900{ }^{\circ} \mathrm{C}, \boldsymbol{v}_{\mathbf{P Z}}=0.5 \mathrm{~mm} / \mathrm{h}$. The pyrolysis zone was "pulled" by $3 \mathrm{~mm}$ beyond the outer surface of the CCFs $(\boldsymbol{R}=38 \mathrm{~mm})$. At this point, the heating of the blank was inadvertently turned off and then turned on. The billet was cooled from 900 to $300{ }^{\circ} \mathrm{C}$ at a rate of $1200{ }^{\circ} \mathrm{C} / \mathrm{h}$ and heated, in a compressed state, to $900^{\circ} \mathrm{C}$ at a rate of $3000{ }^{\circ} \mathrm{C} / \mathrm{h}$, with the following rising of the $\mathrm{T}$, at this point, from 900 to $1050{ }^{\circ} \mathrm{C}$, for $10 \mathrm{~h}$. This resulted in a significant PyC densification of the asbestos shell of the container. The billet was cooled from 1050 to $150{ }^{\circ} \mathrm{C}$ at a speed of $1020 \ldots 450{ }^{\circ} \mathrm{C} / \mathrm{h}$.

After being removed from the pyrolysis chamber, the container was intact. A day later, a vertical crack appeared along the entire height. After turning to $\varnothing 67 \mathrm{~mm}$, at the ends adjacent to the current concentrators, the same cracks were found as in the experiment 1 (see Fig. 4), on the outer surface - a network of longitudinal and transverse cracks (Fig. 7). Longitudinal cracks and cracks on current concentrators are the result of thermal shock. Transverse cracks were formed due to the difference between the CLTEs of the CCFBPyC and the shell of the container, significantly densified with PyC.

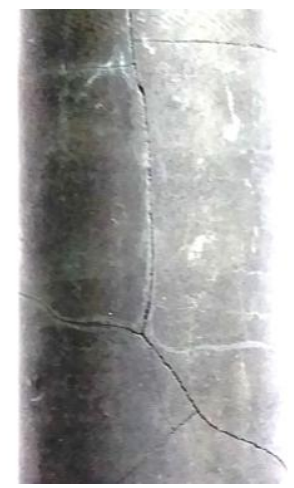

Fig. 7 Cracks in the

CCFBPyC, ShP-13

There was no decrease in $\Delta \boldsymbol{T}$ when installing the screen and increasing $\boldsymbol{\rho}_{\text {COMP }}$ of CCFs from 0.47 to $0.60 \mathrm{~g} / \mathrm{cm}^{3}$ (Fig. 10, exp. 4, curves 1 and 2). This is most likely due to the lower heat conductivity of the CCFs ShP-13, compared to the CCFs ShP-10, because of the longer time of its production (64 and $59 \mathrm{~h})$ and the higher soot content.

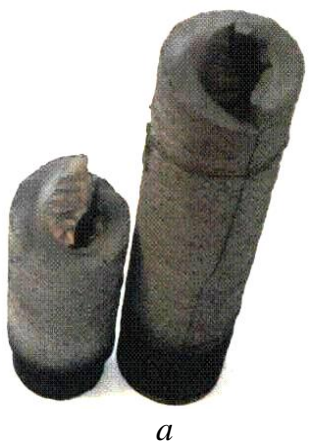

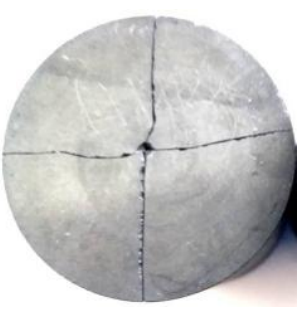

b

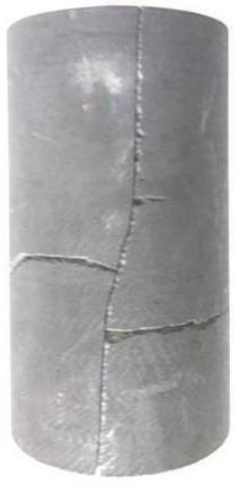

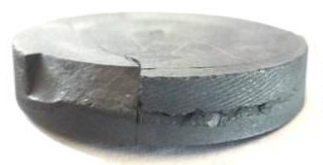

d

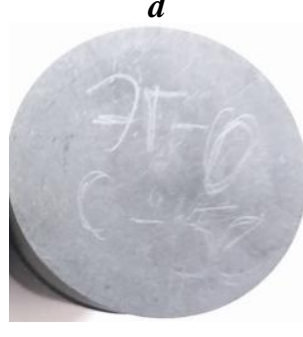

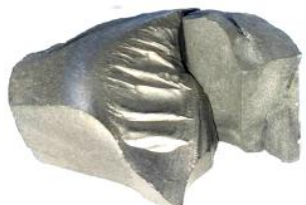

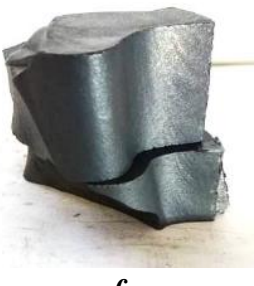

$f$

Fig. 8. The nature of the destruction of CCFBPyC based on thermally refined CCFs ShP-16R (exp. 3): $a$ - the diameter of the compacted PyC billet is $75 \mathrm{~mm} ; b-f$-the diameters of the component parts of the billet, after turning are equal to $67 \mathrm{~mm}$
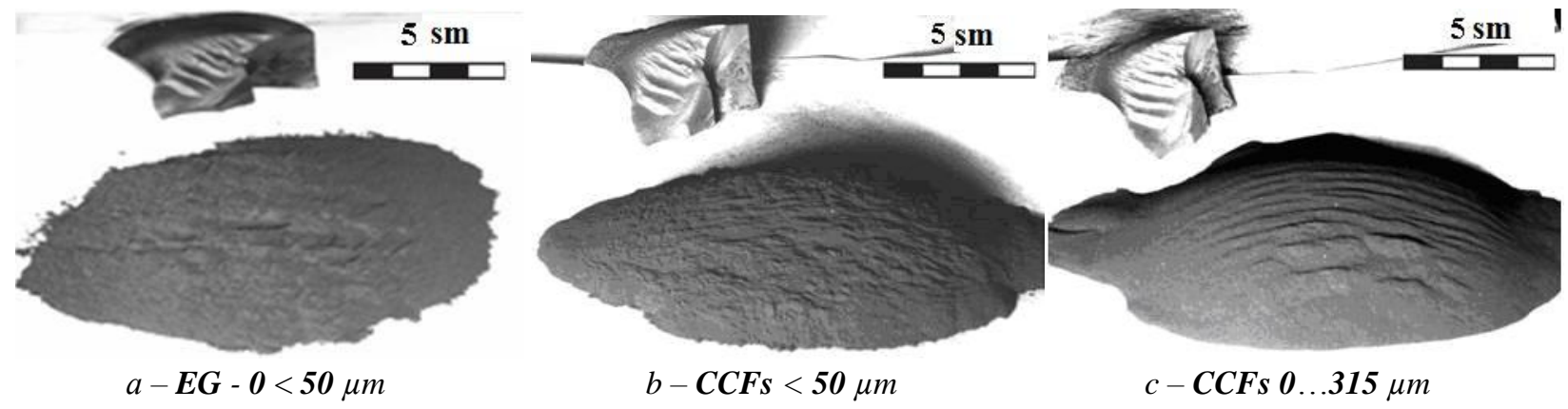

Fig. 9. The general view of graphite powder (a) and CCFs $(b, c)$ 


\section{EXPERIMENT 3}

According to literature data [2], annealing of CNTs in vacuum already at $1500 \ldots 1800{ }^{\circ} \mathrm{C}$ cleans them of the catalyst and impurities and improves the structure. In this connection, in experiment 3, the CCFs from the process ShP-16, purified from $\mathbf{N i}$ by thermal refining in a vacuum of $\mathbf{1 0}^{-3} \mathrm{~atm}$, at $2650^{\circ} \mathrm{C}$, for $0.5 \mathrm{~h}$ [15] - ShP. 16R, were used. The parameters of the CCFs and CCFBPyC are given in Table 1.

When preparing the exp. 3 surface cracking in the blank of the exp. 2 had not yet been identified. Therefore, to obtain the results comparable with exp. 2, the blank was molded in an asbestos shell $\mathbf{3}$ and screen $\mathbf{9}$ was installed (see Fig. 3,a). The CCFs was not enough to fill the whole container, therefore, buffer 10 of EG-0 powder, with fraction $0 . .50 \mu \mathrm{m}$ was filled and shaken under the lid (see Fig. 3,a).

PyC densification was carried out according to the mode: $\quad \boldsymbol{T}_{\mathbf{P Z}}=900{ }^{\circ} \mathrm{C}, \quad \boldsymbol{v}_{\mathbf{P Z}}=0.5 \mathrm{~mm} / \mathrm{h} . \quad$ At $\quad \boldsymbol{R}_{\mathbf{P Z}}=$ $22.5 \mathrm{~mm}$, a thermocouple (TCA) was introduced into $\boldsymbol{R}_{\mathbf{P Z}}=15.5 \mathrm{~mm}$, with $\boldsymbol{T}_{\mathbf{P Z}}=950{ }^{\circ} \mathrm{C}$. Further, at $\boldsymbol{R}_{\mathbf{P Z}}=$ $18 \mathrm{~mm}$, in the case of emergency shutdown of the installation, the container was cooled from 950 to $300^{\circ} \mathrm{C}$ with the velocity $=1300{ }^{\circ} \mathrm{C} / \mathrm{h}$, with its subsequent heating to $950{ }^{\circ} \mathrm{C}$, with the velocity $=3900{ }^{\circ} \mathrm{C} / \mathrm{h}$. Cooling was adjustable, with the velocity $=150{ }^{\circ} \mathrm{C} / \mathrm{h}$. The blank, removed from the pyrolysis chamber, divided into 2 parts (см. Fig. 8,a), due to the thermal shock, in a compressed state, at $\boldsymbol{R}_{\mathbf{P Z}}=18 \mathrm{~mm}$.

The experiments were stopped to analyze the causes of the destruction. The following studies were carried out:

1. A workpiece with $\varnothing 75 \mathrm{~mm}$ was turned on a lathe to $\varnothing 67 \mathrm{~mm}$, cut into component parts and photographed (see Fig. 8).

Above the bottom current concentrator, the same cracks were found as in the experiment 2 (see Fig. 8,b), with their transition into the workpiece (see Fig. 8,c). Delamination and cracks were found in the CCFBPyC, at the junction with the GBPyC-EG-0, with their transition to the GBPyC (see Fig. 8,d). There were no cracks in the GBPyC-EG-0 buffer, under the current concentrator (see Fig. 8,e). The fracture surface of the CCFBPyC obviously repeats the structure of the CCFs stacking, which was formed on a vibration stand, with the orientation of the particles perpendicular to the workpiece axis (see Fig. 8,f). The opalescent fracture surface indicates about the separation of the CCFBPyC along the grain boundaries, that, most likely, can occur with a small thickness of the PyC layer at these boundaries. Destruction of the workpiece in the exp. 3 (and the workpiece shown in Fig. 2,b) happened in the middle of the process, and not at the end, as in exps. 1, 2. The cracks in it should have been filled with either the soot, densified with PyC, or PyC. This, however, did not happened and, quite possible, due to the composition of the gas medium (excess of hydrogen) both in the volume of cracks and in the transport porosity of the CCFs, namely:

- excess hydrogen in cracks can be formed due to its flow from the pyrolysis zone into the volume of cracks;
- the entangled, finely dispersed structure of the CCFs can hinder the diffusion of methane into the pyrolysis zone both during the formation of the CCFs and its gas-phase densification with $\mathrm{PyC}$, forming a gaseous medium with an excess of hydrogen, the inhibitory effect of which on the formation of $\mathrm{PyC}$ is given by P.A. Tesner in the monograph [13]. Indirect confirmation of difficult diffusion of methane can be:

- during the formation of CCF $-30 \ldots 40 \mathrm{wt} . \%$ soot in the composition of CCFs [10];

- during gas-phase densification $\mathrm{PyC}$ - data of the RF patent No. RU 2568733 [17], according to which in a frame with a density of $0.6 \ldots 0.65 \mathrm{~g} / \mathrm{cm}^{3}$, based on low-modulus carbon fibers, it is impossible to ensure a content of catalytically deposited carbon of more than $4.2 \mathrm{wt} . \%$, since with an increase of its content, the diffusion rate of carbon-containing gas into the pores of the framework sharply decreases.

2. It was found that CCFs, with fractional composition of $0 \ldots 50,0 \ldots 315 \mu \mathrm{m}$, adhere to each other, forming stable slip planes (Fig. 9,b,c), which promote agglomeration of CCFs into anisotropic structures, during formation of the blanks. In graphite EG-0, such stable planes are absent (see Fig. 9,a).

3. Microsections of the samples from the middle of the blanks from the exps. 1-3 were made. On the sections from the exps. 2, 3, a close-packed structure of large grains (with an average size of $200 \times 200 \mu \mathrm{m}$ ) is observed in a monolith of small ones, with a PyC layer thickness at the grain boundary: $\mathbf{0 . 5} \ldots 1.0 \mu \mathrm{m}-$ in exps. 1,$3 ; 3 . .5 \mu \mathrm{m}-$ in exp. 2 . Closed porosity of the workpiece from the exp. 3 is elongated along the radius (laying the CCFs perpendicular to the axis, during molding). On the section from exp. 3, a chain of closed pores, connected by cracks passing through the monolithic material, was discovered. This may be the evidence that the gas in closed pores is capable of creating internal thermal stresses, leading to the destruction of the material.

4. From the theory of strength it is known that the work of brittle fracture depends on the micro- and crystalline structure, test conditions and decreases with an increase in the loading rate, the presence of stress concentrators. The rate of temperature rise of workpieces compressed by current concentrators, after emergency modes, in exps. 1-3, apparently proportional to the loading rate, was $2000 \ldots 4000^{\circ} \mathrm{C} / \mathrm{h}$. Current concentrators were, at the same time, stress concentrators. In the workpiece (see Fig. 2,b), densified according to the mode: $\boldsymbol{T}_{\mathbf{P Z}}=900{ }^{\circ} \mathrm{C}, \boldsymbol{v}_{\mathbf{P Z}}=0.33 \mathrm{~mm} / \mathrm{h}, \boldsymbol{C}_{\mathbf{N i}}=2.67 \mathrm{wt} . \%$, the current concentrators were replaced by a heater made of a bundle of URAL-NSh threads, but this attempt to avoid its destruction was unsuccesfull. This may indicate that the CCFBPyCs are destroyed under the action of its own stresses in the structure, and stress concentrators only promote them. Therefore, to check the possibility of destruction of the anisotropic structures of the CCFBPyCs by internal thermal stresses, samples from exp. 1 and 3 were subjected to thermal shocks in methane, with different heating and cooling rates and holding, at $\boldsymbol{T}_{\mathbf{E X P}}$, for $0.5 \mathrm{~h}$ (Table 3 ). 
Table 3

Modes of heat treatment of CCFBPyCs samples

\begin{tabular}{|c|c|c|c|}
\hline $\begin{array}{c}\text { Exp. } \\
\text { No }\end{array}$ & $\begin{array}{c}\text { Temperature } \\
\text { range }\end{array}$ & $\begin{array}{c}\text { Heating rate, } \\
{ }^{\circ} \mathrm{C} / \mathrm{h}\end{array}$ & $\begin{array}{c}\text { Cooling rate, } \\
{ }^{\circ} \mathrm{C} / \mathrm{h}\end{array}$ \\
\hline 1 & $100 \ldots 400$ & 150 & 1500 \\
\hline 2 & $30 \ldots 600$ & 1700 & 500 \\
\hline 3 & $30 \ldots 800$ & 2900 & $6000 \ldots 1500$ \\
\hline 4 & $30 \ldots 1000$ & 2530 & 7000 \\
\hline
\end{tabular}

The samples did not undergo any changes, which indicated that the destruction of the CCFBPyCs occurs along the boundaries of the structural inhomogeneities of the workpiece, under the influence of external stresses.

The following conclusions were made from the analysis:

1) brittle fracture of CCFBPyCs is determined by the morphology of CCFs, namely: agglomerates of CCFs, linked by a fine fibrous fraction, create a specific finepored structure in the workpiece, which impedes the diffusion of methane into the pyrolysis zone. This structure forms a PyC matrix with a small PyC layer thickness. The strength of the matrix is insufficient to resist internal and external stresses. Therefore, the workpiece is destroyed along the boundaries of structural inhomogeneities embedded in it during molding (see Fig. 2,b; 8,f). In this regard, the isotropy of the CCFs moldings is fundamentally important. It can be provided, in particular, by manual ramming with or without shaking the container;

2) to increase the strength of the $\mathrm{PyC}$ matrix, it is necessary to increase the thickness of the PyC layer by increasing the transport porosity of the material. This improves the supply of methane and the removal of products of its decomposition from the pyrolysis zone. This can be achieved by: reducing the bulk density of the CCFs (manual filling without a shaker), its preliminary agglomeration with any (including $\mathrm{PyC}$ ) binders, the introduction of pore-forming additives (salt, sugar, glycerin, PVA, phenol-formaldehyde resin, etc.), the selection of the fractional composition, in particular, the removal of finely dispersed CCFs nanostructures;

3) when using other methods of the densification of CCFs with PyC: densification without a screen, decrease in $\mathbf{v}_{\mathbf{P Z}}$ (the workpiece shown in Fig. 2,b collapsed at $\boldsymbol{v}_{\mathbf{P Z}}=0.25 \mathrm{~mm} / \mathrm{h}$ ), an increase in $\boldsymbol{T}_{\mathbf{P Z}}$, remains and again forms on the catalyst, fine nanostructure of CCFs and low-strength $\mathrm{PyC}$ matrix, repeating it.

It has been hypothesized that this has been the main reason for the failure to obtain CCFBPyCs without cracking for the present time. To test this assumption, in exps. 4,5 , a fraction of $0 \ldots 50 \mu \mathrm{m}$, which consist mainly of such nanostructures, was removed from the CCFs.

\section{EXPERIMENT 4}

When preparing exp. 4, the technological factors, contributing to the brittle destruction of CCFBPyC (see Fig. 3,b), were excluded:

- the shell container $\mathbf{3}, \varnothing 70 \mathrm{~mm}$, formed from a single-layer AT-3 asbestos cloth and used in exps. 1-3 was replaced with the shell container, made from a 1 layer of URAL-T-22 carbon fabric;
- a fraction of $50 \ldots 315 \mu \mathrm{m}$ of powder ShP-16R, obtained after deleting $0 . .50 \mu \mathrm{m}$ fraction of this powder was used in the experiment. The parameters of CCFs and CCFBPyC are given in Table 1;

- for isolation of current concentrators from CCFs, the buffers $\mathbf{1 0}$ of graphite powder EG-0, fraction $50 \ldots 200 \mu \mathrm{m}$ were filled in and shaken on them;

- for comparability with the results of previous experiments and for alignment of the radial and vertical gradients $\boldsymbol{T}$, screen 9 and supports 1, 7, Ø 60x100 mm, with increased electrical resistance, were installed, respectively.

The densification of the CCFs was carried out according to the mode: $\boldsymbol{T}_{\mathbf{P Z}}=900{ }^{\circ} \mathrm{C}, \boldsymbol{v}_{\mathbf{P Z}}=0.5 \mathrm{~mm} / \mathrm{h}$. At $\boldsymbol{R}_{\mathbf{P Z}}=12.5 \mathrm{~mm}$, TCA was entered into $\boldsymbol{R}_{\mathbf{P Z}}=6.5 \mathrm{~mm}$, with $\boldsymbol{T}_{\mathbf{P Z}}=950{ }^{\circ} \mathrm{C}$.

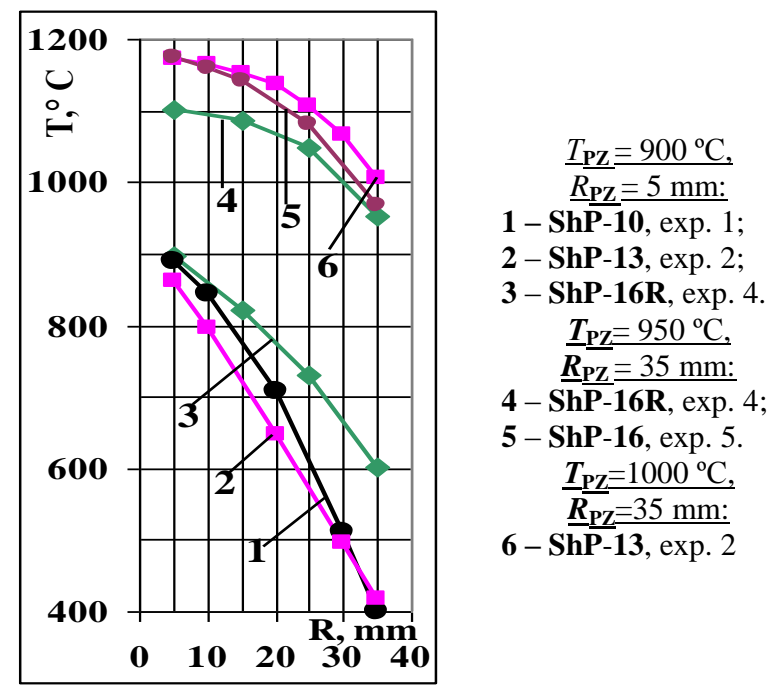

Fig. 10. Temperature distribution $(\boldsymbol{T})$ along the container radius $(\boldsymbol{R})$ in exps. 1, 2, 4, 5 Table 4

Temperature gradients in experimet 4

\begin{tabular}{|c|c|c|c|c|c|c|c|c|}
\hline \multirow{2}{*}{$\begin{array}{c}\text { Curve } \\
\text { No }\end{array}$} & \multirow{2}{*}{$\begin{array}{l}R_{\mathrm{PZ}} \\
\mathrm{mm}\end{array}$} & \multirow{8}{*}{$\begin{array}{c}\Delta T, \\
{ }^{\circ} \mathrm{C} / \\
\mathrm{mm}\end{array}$} & \multicolumn{6}{|c|}{$R, \mathrm{~mm}$} \\
\hline & & & 10 & 15 & 20 & 25 & 30 & 35 \\
\hline 1 & 5 & & 9 & \multicolumn{2}{|c|}{14} & \multicolumn{2}{|c|}{19.5} & 22 \\
\hline 2 & 5 & & 13 & \multicolumn{2}{|c|}{15} & \multicolumn{2}{|c|}{15} & 16 \\
\hline 3 & 5 & & \multicolumn{2}{|c|}{7.5} & \multicolumn{2}{|c|}{9} & \multicolumn{2}{|c|}{13} \\
\hline 4 & 35 & & \multicolumn{2}{|c|}{2} & \multicolumn{2}{|c|}{4} & \multicolumn{2}{|c|}{10} \\
\hline 5 & 35 & & 3 & 3.4 & \multicolumn{2}{|c|}{6} & \multicolumn{2}{|c|}{11.4} \\
\hline 6 & 35 & & 1.4 & 2.4 & 3.2 & 6 & 8 & 12 \\
\hline
\end{tabular}

Comparison of temperature distribution and $\Delta \boldsymbol{T}$ (Fig. 10, Table 4) in thermo-refined and non-thermorefined CCFs, both at the beginning (curves 3 and 1, 2) and at the end of the process (curves 4 and 5, 6) indicates an increase in its heat conductivity, due to the removal of the low-heat-conductivity fraction $0 \ldots 50 \mu \mathrm{m}$ and partial graphitization, after annealing at $T=$ $2650{ }^{\circ} \mathrm{C}$.

After the completion of densification and turning to Ø $67 \mathrm{~mm}$, no damage was found in the workpiece (Fig. 11). The thickness of the PyC layer in the CCFBPyC was 7...30 $\mu \mathrm{m}$. 


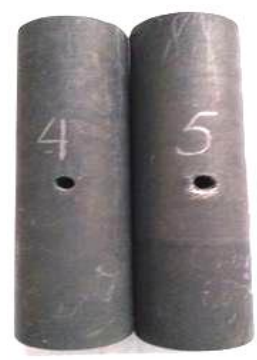

Fig. 11. CCFBPyC machined blanks from the exps. 4, 5

\section{EXPERIMENT 5}

Exp. 5 was carried out according to the scheme of exp. 4 (see Fig. 3,b). In the experiment, a fraction of $50 \ldots 315 \mu \mathrm{m}$ of powder ShP-16 was used, with $\boldsymbol{C}_{\mathrm{Ni}}=$ 1.64 wt.\%. The parameters of CCFs and CCFBPyC are given in Table 1. Additionally, to reduce the vertical gradient $\boldsymbol{T}$, the $\varnothing$ of the supports $\mathbf{1 . 7}$ was reduced to $50 \mathrm{~mm}$, and the current concentrators 2, 5 were made of GBPyC-EG-0, with a specific electrical resistance 2 times higher than that of the EG-0. The densification of the CCF was carried out according to the mode: $\boldsymbol{T}_{\mathbf{P Z}}=900{ }^{\circ} \mathrm{C}, \boldsymbol{v}_{\mathbf{P Z}}=0.5 \mathrm{~mm} / \mathrm{h}$. At $\boldsymbol{R}_{\mathbf{P Z}}=26.5 \mathrm{~mm}, \mathrm{TCA}$ was entered into $\boldsymbol{R}_{\mathbf{P Z}}=20.5 \mathrm{~mm}$, with $\boldsymbol{T}_{\mathbf{P Z}}=950{ }^{\circ} \mathrm{C}$. After densification, no damage was found in the workpiece (see Fig. 11). The thickness of the PyC layer in the CCFBPyC was $\mathbf{7} . .30 \mu \mathrm{m}$.

Thus, in exp. 5, it was confirmed that it is possible to obtain a CCFBPyC without cracks on non-cleaned CCFs. The insignificant content of Ni (1.64 wt.\%) does not allow to make an unambiguous conclusion about the influence of the catalyst concentration in the CCFs on the destruction of the CCFBPyC. But, most likely, there will be no need to determine this influence, since purified CNTs and CNMs are used (and are being investigated) all over the world.

Carrying out physical-mechanical and thermophysical studies of the obtained materials will make it possible to clarify the stated assumptions.

Improvement of technologies for production and thermal refining of CNM will allow to receive at NSC KIPT up to $300 \mathrm{~kg}$ of CNM and up to $50 \mathrm{~kg}$ of purified CNM per month.

\section{CONCLUSION}

The conducted studies of pyrocarbon densification of powders of catalytic carbon formations (CCFs) on $\mathrm{Ni}$ showed a direct dependence of their brittle strength from the morphology of CCFs. A decrease in the amount of the finely dispersed fibrous component of the CCFs for the first time allowed to obtain CCCM blanks without cracks, based on purified and not purified from $\mathrm{Ni}$ carbon nanomaterials (CNM). It is necessary to take into account the low thermal strength of CCCM based on CCFs both when forming blanks and densification with PyC, namely:

- molding of CCFs must be carried out using materials, the CLTE of which is not very different from the CLTE of PyC (carbon fabric, GBPyC);

- current concentrators (in the case of the direct passing of an alternate current through the CCFs) should not come into contact with the CCFs;
- the backfill of the CCFs should be maximally isotropic and gas-permeable;

- during densification, both thermal shocks and CCFBPyC lifting/cooling rates above $200{ }^{\circ} \mathrm{C} / \mathrm{h}$ should be excluded. Separately, the need to reduce $\Delta \boldsymbol{T}$ in CCFs requires clarification.

The efficiency of the equipment developed at the NSC KIPT for the method of vacuum-thermal refining of carbon materials has been confirmed [15]. This method is more environmentally friendly than chemical cleaning. Improvement of the equipment will make it possible to clean up to $50 \mathrm{~kg}$ of any CNM per month at the NSC KIPT.

\section{REFERENCES}

1. A.V. Eletskii. Carbon nanotubes // Uspekhi Fizicheskih Nauk. 1997, v. 167, N 9, p. 945-971 (in Russian).

2. E.G. Rakov. Nanotubes and fullenes. M.: "University book". 2006, 235 p.

3. E.G. Rakov. Methods for preparation of carbon nanotubes // Usp. Khim. 2000, v. 69, N 1, p. 41-59.

4. E.G. Rakov. The chemistry and application of carbon nanotubes // Usp. Khim. 2001, v. 70, N 10, p. 934-973.

5. V.F. Zelensky, V.A. Gurin, V.V. Kolosenko, A.E. Bakumenko. Study of the catalytic gas-phase deposition of carbon on metals of the iron subgroup: Research Report UDC 138/30.12.87. Kharkov: KIPT, 1987.

6. V.A. Gurin, I.V. Gurin, D.A. Levin. Research of a precipitation process nanometric of carbonic formations from a gas phase on catalyst - dust of a nickel // Problems of Atomic Science and Technology. Series "Physics of Radiation Effect and Radiation Materials Science" (85). 2004, N 3, p. 81-86.

7. V.A. Gurin, I.V. Gurin, V.V. Kolosenko, V.A. Ksenofontov, T.A. Mazilova. Mechanical strength of carbon nanofibers obtained by catalytic chemical vapor deposition // Pis'ma v Zhurnal Tekhnicheskoŭ Fiziki 2007, v. 33, N 12, p. 83-88 (in Russian).

8. O.A. Velikodnaya, V.A. Gurin, I.V. Gurin, V.V. Kolosenko, V.A. Ksenofontov,. Multi-emitter field ion source based on a nanostructural carbon material // Pis'ma v Zhurnal Tekhnicheskoü Fiziki 2007, v. 33, N 13, p. 90-94 (in Russian).

9. I.V. Gurin, B.P. Vvedens'kyy, V.A. Gurin, A.N. Bukolov, S.G. Fursov. Obtaining of long length carbon catalytic formations and investigation of their biocompatibility // Biotekhnolohiia. 2011, v. 4, N 2, p. 54-60.

10. V.A. Gurin, S.V. Gabelkov, N.S. Poltavtsev, I.V. Gurin, S.G. Phursov. Crystal structure of pyrographite and catalytically deposited carbon // Problems of Atomic Science and Technology. Series "Physics of Radiation Effect and Radiation Materials Science” (89). 2006, N 4, p. 195-199.

11. S.V. Mischenko, A.G. Tkachev. Carbon nanomaterials. Fabrication, properties and applications // M.: "Mechanical Engineering”, 2008, 320 p.

12. A.V. Ruhov. Basic processes and instrumentation for the production of carbon nanomaterials: Ab- 
stract of dissertation for the degree of Doctor of Technical Sciences. Ivanovo, 2013, p. 1-32.

13. P.A. Tesner. Carbon formation from the gasphase hydrocarbons. M.: "Khimiya", 1972, p. 20-66.

14. A.V. Eletskii Sorption properties of carbon nanostructures // Uspekhi Fizicheskih Nauk. 2004, v. 174, N 11, p. 1213-1228 (in Russian).

15. I.V. Gurin, V.A. Gurin, Yu.A. Gribanov, Ya.V. Kravtsov, A.N. Bukolov, V.V. Gujda, V.V. Kolosenko. High-purity carbon composite materials // Problems of Atomic Science and Technology. Series
"Physics of Radiation Effect and Radiation Materials Science” (89). 2014, N 1, p. 16-20.

16. I.V. Zolotukhin, I.M. Golev, A.E. Markova, Yu.V. Panin, Yu.V. Sokolov, A.G. Tkachev, V.L. Negrov. Some properties of solid fractal structures in carbon nanofibers // Zhurnal Tekhnicheskoŭ Fiziki .2006, v. 32, N 5, p. 28-32 (in Russian).

17. Patent RU № 2568733 from 20.11.2015. Application № 2014115831 from 18.04.2014.

Article received 05.03.2021

\title{
ИССЛЕДОВАНИЕ ОСОБЕННОСТЕЙ УПЛОТНЕНИЯ ПИРОУГЛЕРОДОМ ПОРОШКОВ КАТАЛИТИЧЕСКИХ ОБРАЗОВАНИЙ УГЛЕРОДА (КОУ) НА НИКЕЛЕ
}

\author{
С.Г. Фурсов, В.В. Гуйда, С.А. Ляшенко, М.В. Мельтюхов, Е.С. Аулова
}

Исследовано газофазное уплотнение пироуглеродом порошков каталитических образований углерода (КОУ) на Ni методом радиально движущейся зоны пиролиза. Показана прямая зависимость хрупкой прочности уплотненных порошков от морфологии КОУ. Установлено, что уменьшение количества мелкодисперсной волокнистой составляющей КОУ увеличивает прочность пироуглеродной матрицы. Впервые получены углерод-углеродные композиционные материалы (УУКМ) без трещин на основе очищенных и не очищенных от Ni углеродных наноматериалов (УНМ).

\section{ДОСЛІДЖЕННЯ ОСОБЛИВОСТЕЙ УЩІЛЬНЕННЯ ПІРОВУГЛЕЦЕМ ПОРОШКІВ КАТАЛІТИЧНИХ УТВОРЕННЬ ВУГЛЕЦЮ (КУВ) НА НІКЕЛІ}

\author{
С.Г. Фурсов, В.В. Гуйда, С.О. Ляшенко, М.В. Мельтюхов, О.С. Аулова
}

Досліджене газофазне ущільнення піровуглецем порошків каталітичних утворень вуглецю (КУВ) на Ni за допомогою методу зони піролізу, що радіально рухається. Показана пряма залежність крихкої міцності ущільнених порошків від морфології КУВ. Встановлено, що зменшення кількості дрібнодисперсної волокнистої складової КУВ збільшує міцність піровуглецевої матриці. Вперше отримані вуглець-вуглецеві композиційні матеріали (ВВКМ) без тріщин на основі вуглецевих наноматеріалів (ВНМ) з видаленим та невидаленим нікелем. 